\title{
The dependence of minimum-time routes over the North Atlantic on cruise altitude
}

Article

Accepted Version

Mangini, F., Irvine, E. A., Shine, K. P. and Stringer, M. A. (2018) The dependence of minimum-time routes over the North Atlantic on cruise altitude. Meteorological Applications, 25 (4). pp. 655-664. ISSN 1469-8080 doi:

https://doi.org/10.1002/met.1733 Available at https://centaur.reading.ac.uk/76398/

It is advisable to refer to the publisher's version if you intend to cite from the work. See Guidance on citing.

To link to this article DOI: http://dx.doi.org/10.1002/met.1733

Publisher: Royal Meteorological Society

All outputs in CentAUR are protected by Intellectual Property Rights law, including copyright law. Copyright and IPR is retained by the creators or other copyright holders. Terms and conditions for use of this material are defined in the End User Agreement.

\section{www.reading.ac.uk/centaur}

\section{CentAUR}

Central Archive at the University of Reading 
Reading's research outputs online 


\title{
The dependence of minimum-time routes over the North Atlantic on cruise altitude
}

\author{
Fabio Mangini, Emma A. Irvine, Keith P. Shine* and Marc A. Stringer ${ }^{1}$ \\ Department of Meteorology, University of Reading, Earley Gate, Reading RG6 \\ 6BB, UK
}

*Corresponding Author: k.p.shine@reading.ac.uk

${ }^{1}$ Present affiliation: UKESM Core Development Team, NERC National Centre for Atmospheric Science.

\section{Meteorological Applications}

Submitted: 10 July 2017: Revised 16 January 2018: Accepted 23 March 2018

\section{Abstract}

North Atlantic air traffic is broadly organised into a track system; daily sets of tracks are defined by air traffic control which are vertically stacked, such that the same set of tracks is used for all flight levels, regardless of any vertical variations in wind. This work uses minimumtime routes, previously shown to be a good proxy for the location of the North Atlantic track system, to understand whether vertical variations in wind speed and direction significantly affect minimum-time routes optimised at different altitudes; this is to examine whether (all other factors assumed equal) there is potential for improvements in fuel efficiency. The optimum cruise altitude over the North Atlantic is determined, focusing on the New York London route. It is found that eastbound routes, which take advantage of the jet stream, are on average faster at $250 \mathrm{hPa}$ (flight level (FL) 340) than at $300 \mathrm{hPa}$ (FL300) or $200 \mathrm{hPa}$ (FL390) by approximately 2 minutes (compared to the annual-mean route time of about 330 minutes, assuming a true air speed of $250 \mathrm{~m} \mathrm{~s}^{-1}$ ). For westbound routes, the route time increases with height: aircraft flying at $300 \mathrm{hPa}$ are on average 3 minutes faster than at higher levels (the annual-mean optimum time being about 400 minutes). These estimates are compared with the time penalty which arises from flying a route optimized at $250 \mathrm{hPa}$ at the other two altitudes. The time penalty is generally less than a minute, compared to the minimum-time routes calculated at those altitudes.

Keywords: Aviation, Weather-routing, Jet-stream, North Atlantic

\section{Introduction}

Air traffic over the North Atlantic is currently managed by the use of North Atlantic Tracks (NATs) (e.g. Attwooll, 1983; Attwooll, 1986; Lunnon and Marklow, 1992; Lunnon, 1998; ICAO, 2017). These are a set of typically 5-7 flight routes running between the entry and exit points to oceanic airspace (roughly $10^{\circ} \mathrm{W}-50^{\circ} \mathrm{W}$ ) with multiple flight levels available on each route. 
In the planning of NATs, vertical variations in the wind field are not considered despite the NATs system covering the range of cruise altitudes between about 315 to $190 \mathrm{hPa}$ (FL290 to FL410, where FLxx0 stands for flight level at xx thousand feet, defined with reference to a standard atmosphere). NATs are defined twice daily by air traffic control, separately for eastand west-bound flights, in order to adapt them to the prevailing upper level winds and to meet the preferred routes requested by airlines. The upper-level winds over the north Atlantic are characterised by westerly winds and a strong jet stream; therefore, in order to minimize their flight time and maximise fuel efficiency, eastbound flights try to take advantage of the jet stream, whereas westbound flights try to avoid it or, at least, to minimize the headwinds. Both the strength and location of the jet stream vary seasonally (e.g., in winter, the jet tends to be more intense and located further south than in summer) and on a day-to-day basis (e.g. Woollings et al., 2010). As shown in Irvine et al. (2013), these variations are important for aviation as they are reflected in the properties of both eastbound and westbound routes.

Several studies assessing the impact of the upper level winds on trans-Atlantic flights base their analysis on the minimum-time routes between New York and London rather than on the organized tracks system (Irvine et al., 2013; Irvine et al., 2016; Kim et al., 2016; Williams, 2016). In fact there is a good agreement between the two (Irvine et al., 2013) and the properties of the former have the advantage of being more related to the state of the atmosphere, as they are only affected by the winds. Therefore, the minimum-time routes between these two cities will be the basis of this study.

This work seeks to answer two questions. First, taking into account only wind effects, what is the optimum (quickest) flight level, and what is the time penalty for deviating from this level? Second, are routes optimised at different flight levels significantly different?

There are two motivations for identifying the time-optimum flight level and whether the timeoptimum routes differ between flight levels. If all else is considered equal, fuel burn and $\mathrm{CO}_{2}$ emissions are directly related to the flight time hence there are both economic and climate change perspectives.

From an economic perspective, statistics from the International Air Transport Association (http://www.iata.org/pressroom/facts figures/fact sheets/Documents/fact-sheet-industryfacts.pdf) show that between 2010 and 2016, fuel costs for the industry worldwide varied from about US\$150-230 billion, constituting 21 and 33\% of total expenses. Considering that operating profits and net profits are only a small fraction of the fuel costs (varying from US\$18-65 billion and US\$8-36 billion, respectively, over the same period), a simplistic analysis indicates that even a $1 \%$ saving in fuel costs due to reduced flight times could translate into a change in profits which is several times larger. If possibilities for reducing flight times can be identified, an alternative strategy would be to maintain the same flight time but achieve it at a lower cruise speed which, in general, also leads to a fuel saving.

From a climate perspective, the aircraft industry is now committed to achieving "carbon neutral growth" (i.e. maintaining total $\mathrm{CO}_{2}$ emissions from international aviation at 2020 levels via the CORSIA (Carbon Offsetting and Reduction Scheme for International Aviation https://www.icao.int/environmental-protection/Pages/market-based-measures.aspx).

Reductions in fuel burn from any reduction in flight time (or cruise speed) would map directly 
onto a reduction in $\mathrm{CO}_{2}$ emissions, and hence could make carbon-neutral growth easier to achieve.

Answering our two questions would then contribute to a broader consideration of the advantages and drawbacks of flying at particular levels, which would require multidisciplinary input. Changes in flight altitude have implications for the occurrence of turbulence and for contrail production, and other non- $\mathrm{CO}_{2}$ climate effects of aviation (e.g. Grewe et al. 2017). In addition, aircraft are optimised to fly at given altitudes (which depends on aircraft speed) and there are aircraft-dependent penalties for deviating from these (e.g. Airbus 2004). Hence any proposed change in flight altitude would require a consideration of the various trade-offs that such a change would cause.

Our study focuses on NATs, given that it is a major air traffic corridor with typically 600 flights per day (Irvine et al., 2013), which has been estimated to contribute about $6.5 \%$ to total aviation emissions (Wilkerson et al. 2010). Although our quantitative conclusions are specific to that region, they are indicative of the effects that may be found in other regions outside the tropics, where there are significant variations in wind speed with height.

This paper is organized as follows. Section 2 introduces the meteorological data used and how these have been analysed (Section 2.1). It also briefly describes the method used to compute the minimum-time routes (Section 2.2). Section 3 analyses what is the optimum flight level over the North Atlantic, taking into account wind effects, for eastbound (Section 3.1) and westbound (Section 3.2) flights, focusing on the minimum-time routes between New York and London. In Section 3.3 two further city pairs are assessed to see whether these conclusions can be more generally applied to a broader area of the North Atlantic air traffic. Section 4 looks at the differences between minimum-time routes at different flight levels, looking first at how their location varies with altitude (Section 4.1). The time penalty arising from flying at a level different from that at which the route was optimised is analysed in Section 4.2. A general discussion and conclusions are presented in Section 5.

\section{Data and Methodology}

\subsection{Jet stream analysis}

An accurate knowledge of the vertical structure of the wind field over the North Atlantic is required in order to characterise the upper-level winds and to compute the minimum-time routes. Here, wind data were taken from the ERA-Interim reanalysis dataset (Dee et al., 2011) of the European Centre for Medium-Range Weather Forecasts. These data have a horizontal spatial resolution of circa $0.7^{\circ}(\approx 80 \mathrm{~km})$. Even though their temporal resolution is 6 hours, it was found that variations in weather conditions over the course of the day have little impact on trans-Atlantic flights. Therefore, daily averages have been considered instead.

This study uses ERA-Interim reanalysis data from the 33-year period between June 1979 and May 2012. However, the properties of the wind field between June 1990 and May 1992 differed significantly from those observed during other years. Therefore, they have not been used here, meaning that this work is based on 31 years of data. The wind field at three different pressure levels have been considered: at $300 \mathrm{hPa}$ (FL300), $250 \mathrm{hPa}$ (FL340) and 200 hPa (FL390), to span the altitude range of the NATs system. 
Here, attention focuses on the eddy-driven jet stream because of its impact on the minimumtime routes within the North Atlantic flight corridor (e.g. Irvine et al., 2013). Woollings et al., (2010) proposed a simple method to determine the speed and the location of the lower troposphere jet over the North Atlantic. Irvine et al. (2013) showed that this technique can also be used for the jet stream in the upper troposphere-lower stratosphere and that, when related to the properties of the routes, it is able to qualitatively explain their flight times and locations. Therefore, this method has also been used here. Firstly, the North Atlantic is defined as the region between $60^{\circ} \mathrm{W}$ and the prime meridian and between $35^{\circ} \mathrm{N}$ and $75^{\circ} \mathrm{N}$. Secondly, the zonal and meridional component of the wind field over this area is used to calculate the wind speed at each grid point. The wind speed is then zonally averaged across this sector and, for each day, the maximum value of the wind speed and the latitude at which it is located are detected.

Although we use the jet stream definition simply as a diagnostic to help understand the variation in minimum time routes (which are themselves calculated using the full daily-mean horizontal wind speed field), a sensitivity analysis on the method has been performed to test its robustness. To do this, the method has been applied to two additional domains both covering $35^{\circ} \mathrm{N}$ and $75^{\circ} \mathrm{N}$; the West North Atlantic, defined as the region between $60^{\circ} \mathrm{W}$ and $40^{\circ} \mathrm{W}$ and the Central North Atlantic, defined as the region between $45^{\circ} \mathrm{W}$ and $15^{\circ} \mathrm{W}$. In addition, the properties of the jet have been derived using only the zonal component of the winds between $60^{\circ} \mathrm{W}$ and the prime meridian instead of the full wind speed (as in Woollings et al. (2010)). While the absolute value of the diagnosed jet stream varies depending on the choices (by typically 5 to $10 \mathrm{~m} \mathrm{~s}^{-1}$ ) the seasonal variation in jet stream speed, which is one of the main foci here, is little affected.

\subsection{Minimum-time route analysis}

As stated in the Introduction, this study uses minimum-time routes. Irvine et al. (2013) noted a good agreement between the location of the NATs and the minimum-time routes between New York and London which is the principal focus here.

For each day, minimum-time routes have been computed at the 3 different pressure levels for both east- and west-bound flights using the method described by Irvine et al., (2016); this method is also used operationally by the Met Office (Lunnon and Marklow, 1992) to derive minimum-time routes. It is based on the theoretical work of Sawyer (Sawyer, 1949) who derived an equation that an aircraft flying at a constant pressure has to satisfy in order to minimize its flight time:

$$
\frac{d \theta}{d t}=-\frac{\partial u}{\partial n}-\frac{A+u}{S} \cdot \frac{\partial S}{\partial n}
$$

The term on the left-hand side is the rate of change of $\theta$, the aircraft heading. The first term on the right-hand side is the curvature of the wind ( $\mathrm{u}$ is the tailwind, $\mathrm{n}$ is orthogonal and left to the direction pointed by the aircraft), and the second term is associated with the Earth's curvature ( $A$ is the true air speed, $S$ is the scale factor of the projection used in the calculation). For a specified origin (departure airport), the above equation is solved for a set of initial heading angles. The software then selects the route that reaches the destination. 
The results presented here are based on several assumptions. Even though the flight time of trans-Atlantic flights is affected by a number of elements, only the impact of the upper level winds has been considered here. Other factors, such as operational considerations, different types of aircraft, their take-off mass, or engine type have not been included here in order to isolate the meteorological component. Since our analysis focuses on winds at cruise altitude, our minimum-time calculations do not account for the time spent in the take-off and landing phases, and we assume a constant true airspeed of $250 \mathrm{~m} \mathrm{~s}^{-1}\left(900 \mathrm{~km} \mathrm{~h}^{-1}\right.$, Mach number 0.84); small variations in these choices are unlikely to have an impact on our main conclusions. A simplification that might have more impact is our assumption of a constant cruise altitude (because flight altitude tends to increase during each flight as aircraft burn fuel and become lighter) and could be explored in future analyses in this area.

\section{Optimum flight level over the North Atlantic}

This section analyses the optimum cruise altitude (the flight level at which the flight time is minimum) within the North Atlantic Flight corridor.

As stated in the Introduction, eastbound and westbound routes interact with the jet stream in two distinct, almost opposite, ways. It follows that the location of the eastbound and westbound flights will be generally different and, therefore, the vertical structure of the winds experienced by them is also generally different. Hence, eastbound or westbound flights are considered separately.

\subsection{Eastbound flights}

The flight times of the minimum-time routes at the three different levels have been compared. Specifically, for each analysis day, the time difference between flying minimumtime routes at different levels has been calculated by subtracting the $250 \mathrm{hPa}$ route time from that at $300 \mathrm{hPa}\left(\Delta \mathrm{t}_{\mathrm{E}-300}\right)$ and $200 \mathrm{hPa}\left(\Delta \mathrm{t}_{\mathrm{E}-200}\right)$.

The probability density functions (PDFs) of the 4 route time differences are shown in Figure 1. For the eastbound routes, the distributions peak at positive $\Delta t$, indicating that on average it is faster to fly at $250 \mathrm{hPa}$. The tail of the distributions have negative $\Delta \mathrm{t}$ but on $79 \%$ of days it is quicker to fly at $250 \mathrm{hPa}$ than $200 \mathrm{hPa}$, and on $83 \%$ of days it is quicker to fly at $250 \mathrm{hPa}$ than $300 \mathrm{hPa}$. Since the shape of the distributions is approximately Gaussian, their main properties can be summarised by using their mean values and their standard deviations (std). The annual mean time difference $\Delta \mathrm{t}_{\mathrm{E}-300}$ is 1.7 minutes and $\Delta \mathrm{t}_{\mathrm{E}-200}$ is 2.2 minutes (Table 1 ). To place these changes in perspective, the annual mean eastbound route time at $250 \mathrm{hPa}$ is 334 minutes (Table 1), hence these changes are of order $0.5 \%$.

The standard deviations of 2.7 minutes for $\Delta \mathrm{t}_{\mathrm{E}-200}$ and 1.9 minutes for $\Delta \mathrm{t}_{\mathrm{E}-300}$ highlights the day-to-day variability: on a daily basis, the route time differences can significantly diverge from the annual and seasonal averages. Although the time penalty from flying at altitudes other than $250 \mathrm{hPa}$ appears small, as discussed in the Introduction, it does not mean that it is insignificant for airline operators in terms of both $\mathrm{CO}_{2}$ emissions and fuel use. 
Since eastbound flights try to take advantage of the jet stream to reduce flight time, a qualitative explanation of these results can be obtained by comparing the difference in the jet stream speed at the different flight levels. Table 1 shows that the jet is on average stronger at $250 \mathrm{hPa}$ than at 200 or $300 \mathrm{hPa}$, therefore explaining why the flight time is on average minimum at $250 \mathrm{hPa}$.

There is some seasonality to the route time differences. PDFs of the route time differences for each season show similar features to the annual-mean plots (not shown). Table 1 shows that both $\Delta \mathrm{t}_{\mathrm{E}-300}$ and $\Delta \mathrm{t}_{\mathrm{E}-200}$ follow a seasonal cycle and suggests a relationship between them and the seasonal variations of the vertical structure of the jet. The jet speed difference between $300 \mathrm{hPa}$ and $250 \mathrm{hPa}$ is maximum in summer $\left(-2.2 \mathrm{~m} \mathrm{~s}^{-1}\right)$ and is a minimum in spring $\left(-0.4 \mathrm{~m} \mathrm{~s}^{-1}\right)$. This pattern is also found in $\Delta \mathrm{t}_{\mathrm{E}-300}$ : it is maximum in summer (2.6 minutes) and minimum in spring (0.9 minute). Similarly, when the jet speed difference between $200 \mathrm{hPa}$ and $250 \mathrm{hPa}$ is most negative $\left(-4.0 \mathrm{~m} \mathrm{~s}^{-1}\right.$ in spring) $\Delta \mathrm{t}_{\mathrm{E}-200}$ reaches 3.2 minutes, whereas when it is at its least negative (-2.7 $\mathrm{m} \mathrm{s}^{-1}$ in summer) $\Delta \mathrm{t}_{\mathrm{E}-200}$ is only 1.5 minutes. It follows that also on a seasonal basis, $250 \mathrm{hPa}$ remains the fastest level and that, interestingly, the seasonal patterns of $\Delta t_{E-300}$ and $\Delta t_{E-200}$ seem to be in anti-phase. However, it should be noted that there are some discrepancies between the properties of the routes and of the jet. These might arise because of the complex relation between the routes and the upper level winds.

It is noteworthy that the eastbound minimum-time routes are shorter in summer than in spring, despite the mean jet speeds being stronger in spring (Table 1). This is because the minimum-time routes are affected not only by the intensity of the jet, but also by its location. For example, the influence of the jet stream on the minimum-time routes is diminished when the jet is located further from the great circle route between New York and London; because the time saved by taking advantage of the strong tailwinds might not compensate for the time lost because of the longer distance that has to be covered. We find that at $40^{\circ} \mathrm{W}$ the latitude of the jet core is on average 7.1-7.6 degrees from the New York-London great circle latitude in March-April-May, while in June-July-August it is 3.7-4.9 degrees away; in addition, within a few degrees of the great circle latitude itself, the zonal-mean zonal wind is stronger in summer, rather than in spring, even though in general the opposite is the case. In Section 4, where the Miami-Madrid route is considered, it will be shown that the eastbound minimum time routes are shorter in spring than summer, consistent with the fact that the great circle route for this city pair is closer to the peak wind speeds in spring.

\subsection{Westbound flights}

For westbound routes, the distribution of $\Delta \mathrm{t}_{\mathrm{w}-300}$ peaks at negative values (Figure 1), meaning that it is generally quicker to fly at $300 \mathrm{hPa}$ than $250 \mathrm{hPa}$. For $\Delta \mathrm{t}_{\mathrm{W}-200}$ the distribution is centred closer to zero (Figure 1), and it is quicker to fly at $250 \mathrm{hPa}$ than $200 \mathrm{hPa}$ on $59 \%$ of days (Table 2). In the annual mean, routes at $250 \mathrm{hPa}$ are approximately 3 minutes longer than those at $300 \mathrm{hPa}$ and 0.7 minute shorter than those at $200 \mathrm{hPa}$ (these differences are less than $1 \%$ of the typical time for a westbound route). Hence, for westbound routes, the optimum cruise level is $300 \mathrm{hPa}$, in contrast to eastbound routes where the optimum cruise level was $250 \mathrm{hPa}$. $300 \mathrm{hPa}$ is the optimum cruise level in each season (Table 2) and this result is also consistent 
for individual years (not shown). Both $\Delta \mathrm{t}_{\mathrm{W}-300}$ and $\Delta \mathrm{t}_{\mathrm{W}-200}$ are seasonally dependent. $\Delta \mathrm{t}_{\mathrm{W}-300}$ is least negative in spring (-2.3 minutes with $\Delta \mathrm{t}_{\mathrm{W}-300}$ positive $13 \%$ of the days) and most negative in winter ( -3.7 minutes, or about $1 \%$ of $t_{w-250}$, and positive on only $7 \%$ of days). For $\Delta t_{W-200}$ the average route time difference is slightly negative in spring ( -0.3 minute) and reaches its most-positive value in autumn (1.3 minutes). Interestingly, as for the eastbound routes, the changes in $\Delta t_{\mathrm{W}-300}$ and $\Delta \mathrm{t}_{\mathrm{W}-200}$ appear to be in anti-phase.

Westbound flights tend to avoid the jet stream or, at least, to minimize the headwinds (see e.g. Fig. 7 of Irvine et al. 2013). At $40^{\circ} \mathrm{W}$, and $300 \mathrm{hPa}$, about $55 \%$ of flights divert to the north of the jet core, and $45 \%$ to the south (with the frequency of diversions peaking at $\pm 10^{\circ}$ from the jet core) and with only $3 \%$ of routes within $\pm 2.5^{\circ}$ of the jet core. Therefore, it is not possible to find a simple relationship between the route time and the jet speed. However, since the route time is equal to the ratio between the route distance and the velocity, some insight can be gained by analysing the intensity of the headwinds and the length of the minimum-time routes (see Table 3). Table 3 contains two main messages: the intensity of the headwinds increases with height and the $200 \mathrm{hPa}$ minimum-time routes are on average 30 $\mathrm{km}$ shorter than the 250 and the $300 \mathrm{hPa}$ routes (whose length, on the other hand, is similar to $250 \mathrm{hPa}$ ). Weaker headwinds allow the $300 \mathrm{hPa}$ routes to be systematically faster. On the other hand, the averaged time difference between the $200 \mathrm{hPa}$ and the $250 \mathrm{hPa}$ routes is less pronounced because the stronger headwinds at $200 \mathrm{hPa}$ are partly compensated by the shorter extension of the $200 \mathrm{hPa}$ routes.

\subsection{Properties of the minimum-time routes for other city pairs}

The analysis thus far has focused on the New York to London city pair, since this is representative of the bulk of the North Atlantic air traffic. The analysis is extended to include two additional city pairs: Miami - Madrid and Chicago - Copenhagen. Because their great circle routes are, respectively, further south and north of the core of the North Atlantic air traffic, they are used to assess whether the results found for the New York to London route are applicable to a broader area.

The results for eastbound routes for both city pairs are summarized in the upper part of Table 4. As for New York - London, the optimum flight level between Chicago and Copenhagen is $250 \mathrm{hPa}$. This result suggests that this property of the trans-Atlantic flights is also satisfied over the northern flank of the North Atlantic even though minor differences between the two city-pairs exist (for example, for Chicago - Copenhagen, the $200 \mathrm{hPa}$ flights are on average $\approx$ 1 minute longer than those at $250 \mathrm{hPa}$ when compared to New York - London).

By contrast, the optimum flight level for the Miami - Madrid route is $200 \mathrm{hPa}$ (Table 4); on average, the $200 \mathrm{hPa}$ routes are 1.4 minutes faster than those at $250 \mathrm{hPa}$ and 4.6 minutes faster than those at $300 \mathrm{hPa}$. This result can be qualitatively explained by analysing the horizontal and the vertical structure of the upper level winds. As the Miami - Madrid great circle route is to the south of that for New York - London, the flights between Miami and Madrid might be more influenced by the sub-tropical jet stream than by the mid-latitude jet stream. To consider the properties of the strong westerly winds affecting the Miami - Madrid minimum-time routes, a different area to Section 3.1 has therefore been defined, this time between $20^{\circ} \mathrm{N}-55^{\circ} \mathrm{N}$ and between $70^{\circ} \mathrm{W}$ and the prime meridian (i.e. the area is shifted south and extends further west). Even though the results obtained from this new analysis are not 
as clear as in the New York - London case, two main features were found. First, the jet appears to be located on the northern flank of the region in summer (not shown). This is reflected in the properties of the eastbound and westbound routes: between June and August, the route time of the eastbound routes reaches its maximum (about 450 minutes), whereas it is minimum ( $\approx 483$ minutes) for the westbound routes (not shown). Second, between February and May, the jet is located further south and has more influence on the properties of the routes at the different levels. The analysis of the jet speed over this period shows that the stronger winds are located at $200 \mathrm{hPa}$ and that their intensity decreases with height (not shown).

The properties of the westbound routes are summarised in the lower part of Table 4, where only the annual averages are shown. Seasonal means and standard deviations are not included because they do not provide any additional information: for both city pairs, the optimum flight level is not seasonally dependent (the Miami - Madrid westbound routes in the summer seasons are an exception: their route times are not altitude dependent and an optimum flight level is not easily identifiable). On average, the difference between the route time of the $300 \mathrm{hPa}$ and $250 \mathrm{hPa}$ minimum-time routes seems not to be strongly latitude dependent: $\Delta \mathrm{t}_{\mathrm{W}-300}$ is $\mathbf{- 2 . 9}$ minutes for Chicago - Copenhagen and New York - London and -2.5 minutes for Miami - Madrid. By contrast, the difference between the route time at $200 \mathrm{hPa}$ and $250 \mathrm{hPa}$ depends on the city pair considered: $\Delta \mathrm{t}_{\mathrm{W}-200} \approx 2.4$ minutes for Chicago Copenhagen, 0.7 minute for New York - London and 3.7 minutes for Miami - Madrid.

An important conclusion is that the optimum flight level for the westbound routes for all the city pairs studied (Chicago - Copenhagen, New York - London and Miami - Madrid) is $300 \mathrm{hPa}$. Thus, it is a particularly robust property of the trans-Atlantic flights as it shows little route dependence.

\section{Time penalty for not optimizing routes at each flight level}

When the NATs are produced, vertical variations in the upper level winds are not taken into consideration: the same set of organised tracks is used at all altitudes. This section aims to understand whether the current procedure can be improved by evaluating the benefit of optimizing (and hence potentially having different NATs) at each flight level.

\subsection{Variation of location of minimum-time routes with altitude}

First, the preferred locations of the minimum-time routes optimised at each pressure level $(200,250$ and $300 \mathrm{hPa}$ ) are analysed to see whether the routes location varies with altitude. This analysis is based on the following method. The latitude at which the routes intersect the $40^{\circ} \mathrm{W}$ meridian is used as a proxy for their location (as in Irvine et al., 2013). Then, for each analysis day, the location of the minimum-time routes at each pressure level is identified and the result is used to produce the PDFs of the 200, 250 and $300 \mathrm{hPa}$ route locations for both eastbound and westbound flights (Figs. $2 a$ and $2 b$ respectively).

The PDF of the location of the $250 \mathrm{hPa}$ eastbound routes is approximately Gaussian and its peak is slightly further south than the great circle (Fig. 2a). The distribution of the $250 \mathrm{hPa}$ westbound routes is skewed towards high latitudes and peaks at circa $55^{\circ} \mathrm{N}$ (Fig. 2b). Both Figs. $2 \mathrm{a}$ and $2 \mathrm{~b}$ show that the 250 and $300 \mathrm{hPa}$ routes have a similar distribution, suggesting 
only a small difference between the location of the routes at these two levels. By contrast, the distribution for the $200 \mathrm{hPa}$ routes shows some differences. Figure $2 \mathrm{a}$ shows that the PDF for the $200 \mathrm{hPa}$ eastbound routes is centred circa $1^{\circ}$ further south than that for the 250 and $300 \mathrm{hPa}$ flights and it is also more peaked, indicating less variability in the route locations at this level. Figure $2 \mathrm{~b}$ shows that westbound routes at $200 \mathrm{hPa}$ do not extend as far north as those at 250 and $300 \mathrm{hPa}$ and they are located closer to the great circle than the lower level routes.

A qualitative explanation of Figs. $2 a$ and $2 b$ can be obtained by noting the preferred jet locations over the North Atlantic. These have been derived by using a simple technique. For each day, the 200, 250 and $300 \mathrm{hPa}$ wind speed over the North Atlantic (defined as in Section 2.1 as the region between $60^{\circ} \mathrm{W}$ and the prime meridian and between $35^{\circ} \mathrm{N}$ and $75^{\circ} \mathrm{N}$ ) has been computed and zonally averaged. Then, the mean over the 31-year period has been calculated and plotted as a function of latitude (Fig. 3). A comparison between Figs. 2 and 3 shows that the eastbound routes, for which the minimum-time routes tend to maximize the tailwinds, are located in proximity of the wind speed maximum (which is further south than the great circle between New York and London). A closer look at the peaks of the wind speed profiles shows that the jet appears to be tilted in the vertical and to shift southward with height: this is consistent with the routes at $200 \mathrm{hPa}$ being located slightly further south than those at 250 and $300 \mathrm{hPa}$. On the other hand, westbound flights aim to reduce the headwinds to a minimum and are therefore located further north than the great circle, where the wind speed is lower. Interestingly, the wind speed at $200 \mathrm{hPa}$ is weaker than at $250 \mathrm{hPa}$ and 300 $\mathrm{hPa}$ (by approximately $5 \mathrm{~m} \mathrm{~s}^{-1}$ ): weaker head winds might explain why it is possible for the 200 $\mathrm{hPa}$ minimum-time routes to fly closer to the great circle.

Figures 2 and 3 suggest that vertical variations in the horizontal structure of the wind field cause the locations of the minimum-time routes to change with height. It is therefore important to assess whether these can be exploited to improve the NATs system.

\subsection{Penalty for using $250 \mathrm{hPa}$ minimum-time routes at different altitudes}

The vertically-stacked nature of the current NATs structure (where the same NATs are used irrespective of altitude) has been reproduced by using the $250 \mathrm{hPa}$ minimum-time routes between New York and London at all altitudes (therefore flying at $300 \mathrm{hPa}$ and $200 \mathrm{hPa}$ along routes optimised using $250 \mathrm{hPa}$ winds). Since Section 4.1 shows that the location of the minimum-time routes may change with height, flying the $250 \mathrm{hPa}$-optimised route at a different altitude (so that it is a 'non-optimised route') instead of the actual minimum-time route for that particular level should lead to a time penalty. The time penalty for flying a nonoptimised route at, for example, $200 \mathrm{hPa}$ is computed as the time taken to fly the $250 \mathrm{hPa}$ route at $200 \mathrm{hPa}$ minus the time taken to fly the $200 \mathrm{hPa}$ minimum-time route. The results are summarized in Table 5.

Since the distributions of daily time penalty are not Gaussian, the median ( $50^{\text {th }}$ percentile) and the $80^{\text {th }}$ percentile of the data have been used to give information about the centre and the spread of the distributions. For eastbound routes, the median time penalty for flying the $250 \mathrm{hPa}$-optimised route at $300 \mathrm{hPa}$ rather than the $300 \mathrm{hPa}$-optimised route is 0.1 minute, whereas it is circa 0.5 minute at $200 \mathrm{hPa}$. Figures 2 and 3 suggest that there is greater similarity in the location of the 250 and $300 \mathrm{hPa}$ minimum-time routes than of the 250 and 
$200 \mathrm{hPa}$ routes, and therefore could explain why the time penalty for not optimizing at 300 $\mathrm{hPa}$ is smaller than at $200 \mathrm{hPa}$.

For westbound routes, the penalty for not optimizing at $200 \mathrm{hPa}$ and $300 \mathrm{hPa}$ is similar: in both cases, the $50^{\text {th }}$ and the $80^{\text {th }}$ percentiles are comparable and approximately equal to 0.3 minute and 0.8 minute respectively.

In addition, it has been found that the penalty for not optimizing at each flight level is not seasonally dependent.

\section{Summary and Conclusions}

Flights between North America and Europe are strongly affected by the winds at cruise level. Here the properties of trans-Atlantic minimum-time routes were analysed in order to detect any change with height. The aim of this work is to better understand whether the vertical variations in the properties of the routes can be used to make the North Atlantic oceanic airspace more efficient.

This work aimed to answer two main questions: considering only the effect of winds, and therefore assuming all other factors are equal, what is the optimum flight level for transAtlantic flights? And, is there a significant advantage at designing separate sets of NATs for each flight level to exploit vertical variations in the wind field?

First, the minimum-time routes between New York and London were analysed. It was found that the $250 \mathrm{hPa}$ eastbound routes are on average faster than those at $300 \mathrm{hPa}$ and $200 \mathrm{hPa}$ by approximately 2 minutes (i.e. about $0.5 \%$ of the mean flight time). Moreover, the eastbound routes at $200 \mathrm{hPa}$ are located slightly further south than at 250 and $300 \mathrm{hPa}$ : this agrees with the structure of the jet core. The properties of the westbound routes are also altitude dependent. The $300 \mathrm{hPa}$ flights are on average faster than those at $250 \mathrm{hPa}$ and 200 hPa by circa 3 minutes and 3.5 minutes (i.e. between 0.5 and $1 \%$ of the mean flight time) respectively. Vertical variations in the properties of the jet cannot be used to understand these features because westbound routes tend to avoid the jet. However, these results can be qualitatively explained by the fact that the intensity of the averaged headwinds increases with height. Interestingly, it was also found that the $200 \mathrm{hPa}$ routes are able to partly compensate the stronger headwinds by flying closer to the great circle (possibly because the intensity of the jet at $200 \mathrm{hPa}$ is weaker than at 250 and $300 \mathrm{hPa}$ therefore allowing the location of $200 \mathrm{hPa}$ minimum-time routes to be less affected by the winds). For both eastand west-bound routes, the route time difference between different levels is, on average, less than $1 \%$ of the typical route time of trans-Atlantic flights.

The minimum-time routes between Chicago and Copenhagen and between Miami and Madrid were also analysed. They are located further north and further south than New York - London, respectively, and are used to understand whether the conclusions above could be extended to a broader region over the North Atlantic. It was found that some of the properties of the routes depend on the city-pair considered (and, therefore, on the latitude). For example, the optimum flight level for the eastbound routes between Miami and Madrid is $200 \mathrm{hPa}$ and not $250 \mathrm{hPa}$ as for New York - London. However, some of the features appear not to be latitude dependent: notably, the optimum flight level for westbound flights is 300 $\mathrm{hPa}$, regardless of the city-pair considered. 
The second part of the paper focused on the present structure of the NATs and, more precisely, on whether it can be improved by building a set of routes which is optimized at each flight level. The time penalty for using the $250 \mathrm{hPa}$-optimised minimum-time routes to fly at $200 \mathrm{hPa}$ and $300 \mathrm{hPa}$ (rather than routes optimised at $200 \mathrm{hPa}$ and $300 \mathrm{hPa}$ ) was computed. It was found that, for eastbound and westbound routes, the median time penalty was under 30 seconds or less. For eastbound routes the time penalty was larger for flying the $250 \mathrm{hPa}$ routes at $200 \mathrm{hPa}$ than the equivalent situation at $300 \mathrm{hPa}$, which might be a consequence of the $250 \mathrm{hPa}$ routes locations being more similar to those at $300 \mathrm{hPa}$ than at $200 \mathrm{hPa}$. This time penalty appears small in comparison to the effect of the variation in wind with altitude, and suggests that there would be little advantage to defining different sets of North Atlantic tracks at different altitudes.

The savings appear to be a small percentage of total route time. On the one hand, our results could act to reassure airline operators and air traffic managers that any inefficiencies arising from wind variations with height may be small compared to other operational factors (see, for example, Poll (2017)). On the other hand, and as discussed in the Introduction, given ambitious international targets to reduce the growth in aviation $\mathrm{CO}_{2}$ emissions under CORSIA, and the generally small profit margins in this industry, even small savings in $\mathrm{CO}_{2}$ emissions (or, equivalently, fuel use) could be beneficial enough to consider changes in practice, such as improved practice in matching aircraft to routes (e.g. Poll, 2017), which could consider the time-optimum cruise altitude. Clearly other factors would also have to be considered; this includes the effect of changing flight levels on aircraft safety (for example, due to the frequency and severity of turbulence (e.g. Jaeger and Sprenger 2007)) and fuel efficiency, and, potentially, the climate impact of non- $\mathrm{CO}_{2}$ emissions (e.g. Grewe et al., 2017). Even if there is no clear advantage for the present fleet, our results are relevant for design considerations of future aircraft, most particularly in the choice of the aerodynamic optimum cruise altitude; this could be more closely matched to the altitudes for which winds speeds are most beneficial for achieving minimum-time routes, or alternatively, minimising the penalty for variations in cruise altitude.

Acknowledgements: This work was supported by the Natural Environment Research Council, grant NE/J021113/1. This work was inspired by discussions with colleagues at NATS, in particular Jarlath Molloy, Holly Edwards and Andrew Burke. We thank 2 reviewers for constructive comments.

\section{References}

Airbus 2004: Getting to grips with fuel economy. Airbus Flight Operations Support \& Line Assistance. Available from http://ansperformance.eu/references/library/airbus-fueleconomy.pdf (Accessed 16 January 2018)

Attwooll VW. 1982. The North Atlantic organized track structure. J. Navigation 35: 497-499. https://doi.org/10.1017/S0373463300021883.

Attwooll VW. 1986. The economics of the North Atlantic air traffic system. J. Navigation 39: 103-109. https://doi.org/10.1017/S0373463300014284. 
Dee DP, Uppala SM, Simmons AJ, Berrisford P, Poli P, Kobayashi S, Andrae U, Balmaseda MA, Balsamo G, Bauer P, Bechtold P, Beljaars ACM, van de Berg L, Bidlot J, Bormann N, Delsol C, Dragani R, Fuentes M, Geer AJ, Haimberger L, Healy SB, Hersbach H, Hólm EV, Isaksen L, Kållberg $\mathrm{P}$, Köhler M, Matricardi M, McNally AP, Monge-Sanz BM, Morcrette J-J, Park B-K, Peubey C, de Rosnay P, Tavolato C, Thépaut J-N, Vitart F. 2011. The ERA-Interim reanalysis: configuration and performance of the data assimilation system. Q. J. R. Meteorol. Soc. 137: 553-597. https://doi.org/10.1002/qj.828.

Grewe V, Matthes S, Frömming C, Brinkop S, Jöckel P, Gierens K, Champougny T, Fuglestvedt J, Haslerud A, Irvine EA, Shine KP. 2017. Feasibility of climate-optimized air traffic routing for trans-Atlantic flights. Environ. Res. Lett. 12: 1-9. https://doi.org/10.1088/1748-9326/aa5ba0.

ICAO. 2017. 'North Atlantic Operations and Airspace Manual'. International Civil Aviation Organization, European and North Atlantic Office of ICAO: Cedex, France.

Irvine EA, Hoskins BJ, Shine KP, Lunnon RW, Frömming C. 2013. Characterizing North Atlantic weather patterns for climate-optimal aircraft routing. Meteorol. Appl. 20: 80-93. https://doi.org/10.1002/met.1291.

Irvine EA, Shine KP, Stringer MA. 2016. What are the implications of climate change for transAtlantic aircraft routing and flight time? Transport. Res. D-Tr. E. 47: 44-53. https://doi.org/10.1016/j.trd.2016.04.014.

Jaeger EB, Sprenger M. 2007. A Northern Hemispheric climatology of indices for clear air turbulence in the tropopause region derived from ERA40 reanalysis data, J. Geophys. Res., 112: D20106. https://doi.org/10.1029/2006JD008189.

Kim J-H, Chan WN, Sridhar B, Sharman RD, Williams PD, Strahan M. 2016. Impact of the North Atlantic Oscillation on transatlantic flight routes and clear-air turbulence. Journal of Applied Meteorology and Climatology. 55: 763-771. https://doi.org/10.1175/JAMC-D-15-0261.1.

Lunnon RW, Marklow AD. 1992. Optimization of time saving in navigation through an area of variable flow. J. Navigation 45: 384-399. https://doi.org/10.1017/S037346330001095X.

Lunnon RW. 1998. 'Optimum routing in the North Atlantic: costs associated with a constrained system'. Forecasting Research Technical Report No. 249, 5pp. Meteorological Office.

Poll D. 2017. 21st-Century civil aviation: Is it on course or is it over-confident and complacent? - thoughts on the conundrum of aviation and the environment. The Aeronautical Journal, 121: 115-140. https://doi.org/10.1017/aer.2016.140.

Sawyer JS. 1949. 'Theoretical aspects of pressure pattern flying'. Meteorological Report No 3, HMSO.

Wilkerson JT, Jacobson MZ, Malwitz A, Balasubramanian S, Wayson R, Fleming G, Naiman AD, Lele SK. 2010. Analysis of emission data from global commercial aviation: 2004 and 2006. Atmos. Chem.Phys. 10: 6391-6408. https://doi.org/10.5194/acp-10-6391-2010. 
474 Williams PD. 2016. Transatlantic flight times and climate change. Environ. Res. Lett. 11: 1-8. 475 https://doi.org/10.1088/1748-9326/11/2/024008.

476 Woollings T, Hannachi A, Hoskins BJ. 2010. Variability of the North Atlantic eddy-driven jet 477 stream. Q. J. Meteorol. Soc. 136: 856-868. https://doi.org/10.1002/qj.625. 
Table 1: For the eastbound minimum-time routes, annual and seasonal mean and standard deviation of the route time for the $250 \mathrm{hPa}$ routes $\left(t_{E-250}\right)$, and the time difference between the $200 \mathrm{hPa}$ and 250 $h P a$ routes $\left(\Delta t_{E-200}\right)$ and between the $300 \mathrm{hPa}$ and $250 \mathrm{hPa}$ routes $\left(\Delta t_{E-300}\right)$, using 31 years of daily minimum-time routes between New York and London. For these routes, the percentage of days when the route time difference is positive is also shown (\%>0). The annual and seasonal mean and standard deviation of the jet speed at $250 \mathrm{hPa}$ (jet_speed ${ }_{250}$ ) and the difference in jet speed between $200 \mathrm{hPa}$

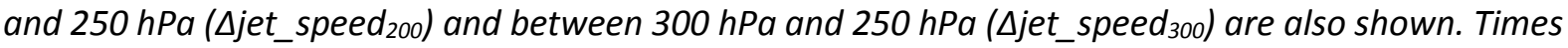
are in minutes, jet speeds are in $\mathrm{m} \mathrm{s}^{-1}$.

\begin{tabular}{|c|c|c|c|c|c|c|c|c|}
\hline & \multirow{2}{*}{$\frac{t_{\mathrm{E}-250}}{\text { Mean } \pm \text { std }}$} & \multirow{2}{*}{$\frac{\text { jet_speed } 250}{\text { Mean } \pm \text { std }}$} & \multicolumn{2}{|c|}{$\Delta \mathrm{t}_{\mathrm{E}-200}$} & \multicolumn{2}{|c|}{$\Delta \mathrm{t}_{\mathrm{E}-300}$} & \multirow{2}{*}{$\frac{\Delta \text { jet_speed }}{200}$} & \multirow{2}{*}{$\frac{\Delta \text { jet_speed }}{300}$} \\
\hline & & & Mean \pm std & $\%>0$ & Mean \pm std & $\%>0$ & & \\
\hline Year & $334.2 \pm 14.0$ & $39.9 \pm 8.6$ & $2.2 \pm 2.7$ & $79 \%$ & $1.7 \pm 1.9$ & $83 \%$ & $-3.3 \pm 3.0$ & $-1.4 \pm 2.2$ \\
\hline Spring & $339.5 \pm 13.8$ & $38.0 \pm 7.5$ & $3.2 \pm 2.9$ & $87 \%$ & $0.9 \pm 1.7$ & $71 \%$ & $-4.0 \pm 3.5$ & $-0.4 \pm 2.4$ \\
\hline Summer & $337.1 \pm 11.2$ & $34.5 \pm 6.1$ & $1.5 \pm 2.2$ & $76 \%$ & $2.6 \pm 1.8$ & $93 \%$ & $-2.7 \pm 2.7$ & $-2.2 \pm 1.8$ \\
\hline Autumn & $331.7 \pm 12.6$ & $41.6 \pm 7.5$ & $1.4 \pm 2.4$ & $72 \%$ & $2.2 \pm 1.8$ & $90 \%$ & $-3.2 \pm 2.6$ & $-1.9 \pm 1.9$ \\
\hline Winter & $328.2 \pm 15.1$ & $45.6 \pm 9.0$ & $2.6 \pm 3.0$ & $81 \%$ & $1.2 \pm 1.8$ & $77 \%$ & $-3.4 \pm 2.9$ & $-1.3 \pm 2.0$ \\
\hline
\end{tabular}

Table 2: For the westbound minimum-time routes, annual and seasonal mean and standard deviation of the route time for the $250 \mathrm{hPa}$ routes ( $\left.t_{w-250}\right)$, of the time difference between the $200 \mathrm{hPa}$ and $250 \mathrm{hPa}$ routes $\left(\Delta t_{\mathrm{w}-200}\right)$ and between the $300 \mathrm{hPa}$ and $250 \mathrm{hPa}$ routes $\left(\Delta t_{\mathrm{w}-300)}\right)$, using 31 years of minimum-time routes between New York and London. The percentage of days when the time differences are positive is also shown (\%>0). Times are in minutes.

\begin{tabular}{|c|c|c|c|c|c|}
\hline & \multirow{2}{*}{$\begin{array}{l}t_{W-250} \\
\text { Mean } \pm \text { std }\end{array}$} & \multicolumn{2}{|l|}{$\Delta t_{\mathrm{W}-200}$} & \multicolumn{2}{|l|}{$\Delta t_{W-300}$} \\
\hline & & Mean \pm std & $\%>0$ & Mean \pm std & $\%>0$ \\
\hline Year & $398.5 \pm 17.2$ & $0.7 \pm 3.5$ & $59 \%$ & $-2.9 \pm 2.6$ & $11 \%$ \\
\hline Spring & $393.0 \pm 16.6$ & $-0.3 \pm 3.4$ & $49 \%$ & $-2.3 \pm 2.2$ & $13 \%$ \\
\hline Summer & $393.8 \pm 12.7$ & $0.7 \pm 2.8$ & $60 \%$ & $-2.5 \pm 2.3$ & $13 \%$ \\
\hline Autumn & $400.9 \pm 15.8$ & $1.3 \pm 3.2$ & $66 \%$ & $-3.3 \pm 2.8$ & $9 \%$ \\
\hline Winter & $406.4 \pm 19.4$ & $1.0 \pm 4.1$ & $62 \%$ & $-3.7 \pm 2.8$ & $7 \%$ \\
\hline
\end{tabular}


500

501

502

503

504

505

506

507

Table 3: For the westbound minimum-time routes, annual and seasonal mean and standard deviation of the headwinds along the $250 \mathrm{hPa}$ minimum-time routes and of the difference between the headwinds at $200 \mathrm{hPa}$ or $300 \mathrm{hPa}$ and the $250 \mathrm{hPa}$ routes. Annual and seasonal mean and standard deviation of the $250 \mathrm{hPa}$ minimum-time route distance and of the difference between the $200 \mathrm{hPa}$ or $300 \mathrm{hPa}$ route distance and the $250 \mathrm{hPa}$ route distance. The analysis uses 31 years of daily minimumtime routes between New York and London.

\begin{tabular}{|c|c|c|c|c|c|c|}
\hline & \multicolumn{3}{|c|}{ Headwind $\left(\mathrm{m} \mathrm{s}^{-1}\right)$} & \multicolumn{3}{|c|}{ Route Distance $(\mathrm{km})$} \\
\hline & $250 \mathrm{hPa}$ & $200-250 \mathrm{hPa}$ & $300-250 \mathrm{hPa}$ & $250 \mathrm{hPa}$ & $200-250 \mathrm{hPa}$ & $300-250 \mathrm{hPa}$ \\
\hline Year & $11.7 \pm 9.3$ & $2.0 \pm 2.7$ & $-1.7 \pm 2.4$ & $5649 \pm 94$ & $-30 \pm 48$ & $0 \pm 43$ \\
\hline Spring & $9.3 \pm 9.1$ & $1.7 \pm 2.4$ & $-1.7 \pm 2.1$ & $5627 \pm 78$ & $-33 \pm 39$ & $7 \pm 37$ \\
\hline Summer & $9.5 \pm 7.5$ & $1.6 \pm 2.7$ & $-1.0 \pm 2.3$ & $5647 \pm 90$ & $-22 \pm 49$ & $-9 \pm 43$ \\
\hline Autumn & $12.4 \pm 8.7$ & $2.2 \pm 2.8$ & $-1.7 \pm 2.6$ & $5663 \pm 103$ & $-27 \pm 51$ & $-4 \pm 47$ \\
\hline Winter & $15.4 \pm 10.3$ & $2.5 \pm 2.9$ & $-2.4 \pm 2.3$ & $5659 \pm 101$ & $-37 \pm 49$ & $8 \pm 42$ \\
\hline
\end{tabular}

Table 4: For eastbound routes (upper), annual and seasonal mean and standard deviation of the 250 $\mathrm{hPa}$ route time $\left(t_{E-250}\right)$ and of the route time difference between the 200 and $250 \mathrm{hPa}$ routes $\left(\Delta t_{E-200}\right)$ and between the 300 and $250 \mathrm{hPa}$ routes $\left(\Delta t_{E-300}\right)$ for the (left) Chicago - Copenhagen and (right) Miami - Madrid city pairs. For westbound routes (lower), annual mean and standard deviation of the $250 \mathrm{hPa}$ route time ( $\left.t_{W-250}\right)$ and of the route time difference between the 200 and $250 \mathrm{hPa}$ routes $\left(\Delta t_{E-200}\right)$ and between the 300 and $250 \mathrm{hPa}$ routes $\left(\Delta t_{w-300}\right)$ for the (left) Chicago - Copenhagen and (right) MiamiMadrid city pairs. Times are in minutes.

\begin{tabular}{|c|c|c|c|c|c|c|}
\hline & \multicolumn{3}{|c|}{ Chicago - Copenhagen } & \multicolumn{3}{|c|}{ Miami - Madrid } \\
\hline & $t_{E-250}$ & $\Delta \mathrm{t}_{\mathrm{E}-200}$ & $\Delta t_{E-300}$ & $t_{E-250}$ & $\Delta \mathrm{t}_{\mathrm{E}-200}$ & $\Delta \mathrm{t}_{\mathrm{E}-300}$ \\
\hline Year & $423.5 \pm 14.3$ & $3.3 \pm 3.1$ & $1.6 \pm 2.6$ & $437.0 \pm 18.0$ & $-1.4 \pm 2.9$ & $3.2 \pm 3.3$ \\
\hline Spring & $427.5 \pm 14.3$ & $4.7 \pm 3.3$ & $0.3 \pm 2.3$ & $435.1 \pm 16.6$ & $-1.9 \pm 3.4$ & $3.7 \pm 4.1$ \\
\hline Summer & $428.1 \pm 11.0$ & $3.3 \pm 2.6$ & $2.7 \pm 2.2$ & $450.1 \pm 11.4$ & $-0.6 \pm 1.9$ & $1.9 \pm 1.9$ \\
\hline Autumn & $419.7 \pm 13.1$ & $2.8 \pm 2.7$ & $2.3 \pm 2.4$ & $438.8 \pm 15.3$ & $-1.5 \pm 2.8$ & $3.5 \pm 3.2$ \\
\hline \multirow[t]{2}{*}{ Winter } & $418.7 \pm 15.5$ & $2.6 \pm 3.3$ & $1.3 \pm 2.8$ & $423.8 \pm 17.6$ & $-1.5 \pm 3.2$ & $3.7 \pm 3.5$ \\
\hline & $t_{W-250}$ & $\Delta t_{\mathrm{W}-200}$ & $\Delta t_{W-300}$ & $t_{W-250}$ & $\Delta t_{W-200}$ & $\Delta \mathrm{t}_{\mathrm{W}-300}$ \\
\hline Year & $473.9 \pm 15.4$ & $2.4 \pm 3.4$ & $-2.9 \pm 2.2$ & $500.0 \pm 21.1$ & $3.7 \pm 4.9$ & $-2.5 \pm 3.5$ \\
\hline
\end{tabular}


Table 5: Time penalty for flying at $200 \mathrm{hPa}$ and $300 \mathrm{hPa}$ along non-optimized routes (the $250 \mathrm{hPa}$

511 minimum-time routes) for east-and west-bound routes. All the 31-year data have been used. In each 512 case, the median (50 5 th percentile) and the $80^{\text {th }}$ percentile of the data are shown. Units are minutes.

\begin{tabular}{ccc}
\hline Flight altitude & \multicolumn{2}{c}{ Time penalty (minutes) } \\
\cline { 2 - 3 } & Eastbound & Westbound \\
\hline $200 \mathrm{hPa}$ & $0.5-1.1$ & $0.3-0.8$ \\
\hline $300 \mathrm{hPa}$ & $0.1-0.4$ & $0.2-0.7$ \\
\hline
\end{tabular}

513 


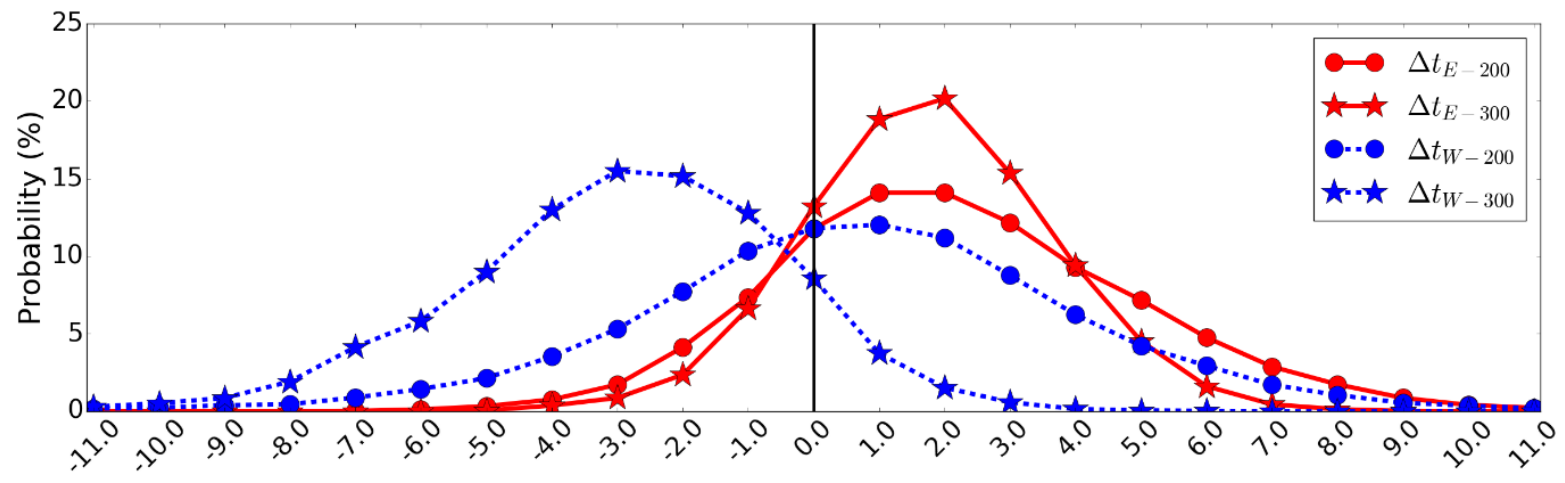

$\Delta t(\min )$

Figure 1: Probability density functions of the route time difference (in minutes) between the $300 \mathrm{hPa}$ and $250 \mathrm{hPa}$ minimum-time routes (stars) and between the $200 \mathrm{hPa}$ and $250 \mathrm{hPa}$ minimum-time routes (circles) using 31 years of daily data for flights between New York and London. Eastbound flights are indicated by a red, straight line, westbound flights by a blue, dashed line.
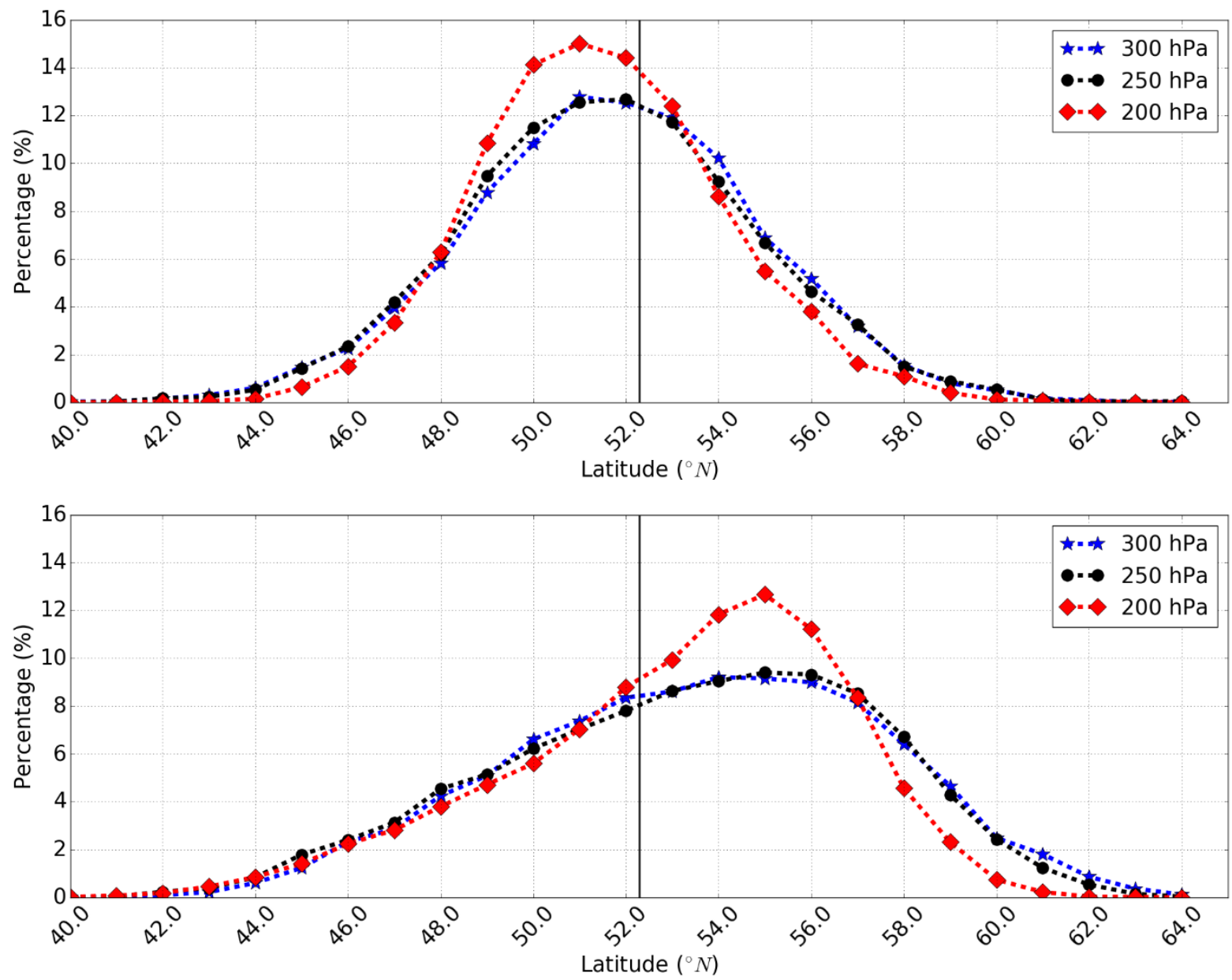

Figure 2: Probability density functions of the latitude at which the (a) eastbound and (b) westbound minimum-time routes at $300 \mathrm{hPa}$ (blue stars), $250 \mathrm{hPa}$ (black circles) and $200 \mathrm{hPa}$ (red triangles) intersect the $40^{\circ} \mathrm{W}$ meridian. The vertical line located at circa $52^{\circ} \mathrm{N}$ represents the latitude of the great circle route between New York and London at $40^{\circ} \mathrm{W}$. The analysis uses 31 years of daily minimum-time routes between New York and London. 


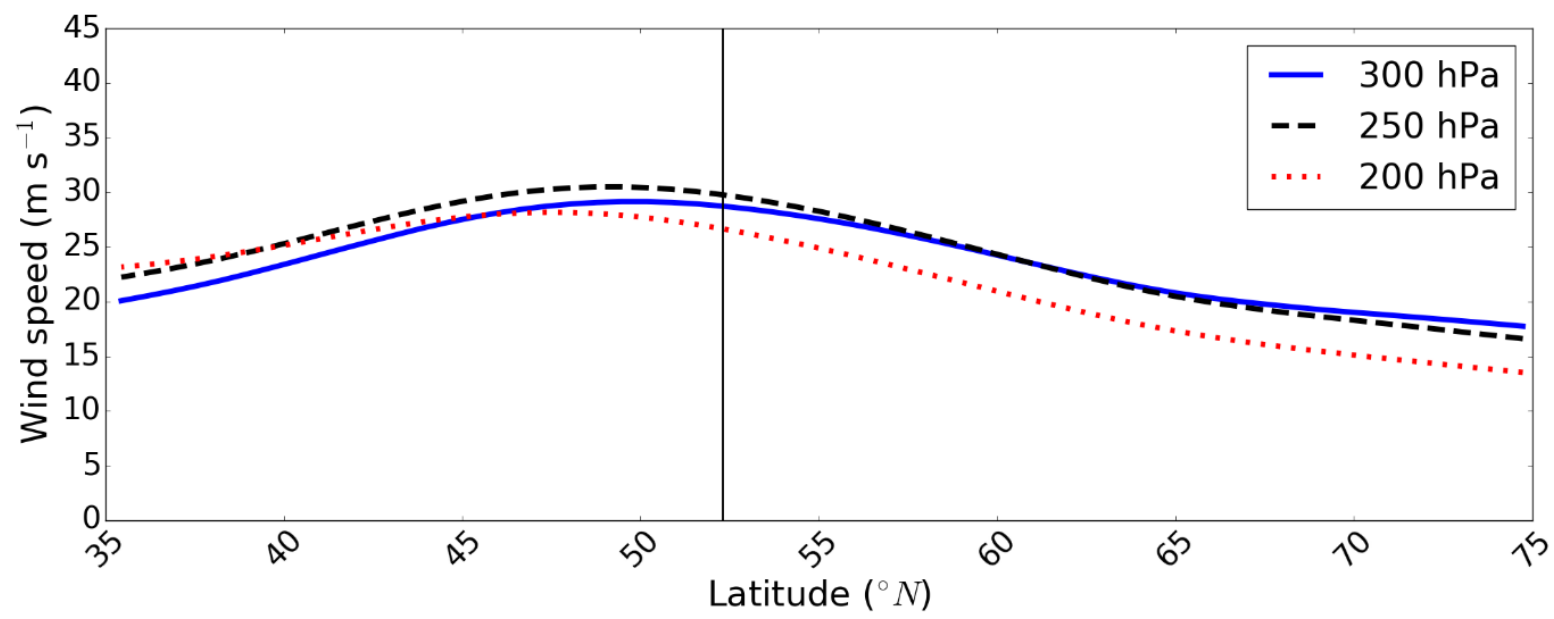

527 Figure 3: Zonally and annually averaged wind speed $\left(\mathrm{m} \mathrm{s}^{-1}\right)$ over the North Atlantic at $300 \mathrm{hPa}$ (blue solid line), $250 \mathrm{hPa}$ (black dashed line) and $200 \mathrm{hPa}$ (red dotted line). The vertical line located at circa $52^{\circ} \mathrm{N}$ represents the latitude of the great circle route between New York and London at $40^{\circ} \mathrm{W}$. 